\title{
ESTUDOS LITERÁRIOS EM PERSPECTIVA: LEITURAS, CONEXÕES
}

\author{
Andréa Figueiredo Leão Grants* \\ Bianca Rosina Mattia** \\ Jair Zandoná ${ }^{* * *}$ \\ Luiz Felipe Alves dos Santos Ungaretti**** \\ Marina Siqueira Drey ${ }^{* * * * *}$ \\ Stélio Furlan ${ }^{* * * * * *}$ \\ Universidade Federal de Santa Catarina
}

A primeira edição de 2018 da revista Anuário de Literatura apresenta às leitoras e aos leitores a nova identidade visual da revista resultante da parceria entre a equipe editorial e a coordenação do Portal de Periódicos da UFSC. Para se chegar a essa nova imagem, vários aspectos foram considerados, a saber, histórico, descrição, público-alvo e a mensagem relacionada à alta qualidade, proficuidade e aprazibilidade da revista. $\mathrm{O}$ resultado foi a criação do header da revista, de um ícone de favorito e uma miniatura para ser usada no sumário do Portal de Periódicos UFSC. A identidade visual é constituída por dois conjuntos de elos sobrepostos formando um arabesco que remete ao mesmo tempo à tradição e à conexão entre a literatura e as leitoras e leitores da revista.

Motivada por essa proposta, nesta edição, a revista Anuário de Literatura apresenta

\footnotetext{
(c) (1) Esta obra está licenciada sob uma Creative Commons - Atribuição 4.0

* Doutora e Mestra em Literatura pela UFSC. Bibliotecária do Sistema de Bibliotecas da UFSC. Coordenou o Portal de Periódicos UFSC (2009/jun.2014). Integra a Comissão Editorial da Anuário de Literatura.

** Mestranda do Programa de Pós-Graduação em Literatura da UFSC. Integra a Comissão Editorial da Anuário de Literatura.

*** Doutor em Literatura pela UFSC. Integra a Comissão Editorial da Anuário de Literatura.

**** Mestrando do Programa de Pós-Graduação em Literatura da UFSC. Integra a Comissão Editorial da Anuário de Literatura.

${ }_{* * * * *}$ Doutoranda do Programa de Pós-Graduação em Literatura da UFSC. Integra a Comissão Editorial da Anuário de Literatura.

${ }_{* * * * * *}$ Doutor e Mestre pela UFSC. Atualmente é Professor Associado junto ao DLLV/UFSC. Atual Editor da Revista da ANPOLL e Editor da revista Anuário de Literatura.
}

Anu. Lit., Florianópolis, v. 23, n. 1, p. 7-10, 2018. ISSNe 2175-7917 
uma seleção composta por textos heterogêneos de temática livre organizados em duas seções: Pesquisadores Docentes e Artigos. Já na sua capa, a arte de Ricardo Henrique Wiggers dialoga com a nova identidade visual da revista. São linhas (in)finitas que, mesmo diversas e (dis)formes, apontam para inúmeros caminhos, daí "a ideia do labirinto: sem fim, interrompido, contínuo, obscuro, visível, etc., mostrando que há várias dificuldades para se chegar ao ponto identificado como o fim", como pondera Wiggers, mas sem esquecer que esses caminhos levam à diversidade que há na literatura.

A seção Pesquisadores Docentes inicia-se pelo texto de Carla Alexandra Ferreira e Raquel Terezinha Rodrigues, intitulado Jane Austen: uma leitura de Becoming Jane (2007), no qual as autoras partem dos pressupostos de transcriação e leitura da narrativa em três horizontes propostas, respectivamente, por Haroldo de Campos e Frederic Jameson, para analisar e rever a biografia fílmica Becoming Jane (2007), dirigida por Julian Jarrold, e como esta traz várias facetas e leituras feitas dos fatos da vida e da obra de Jane Austen.

$\mathrm{Na}$ sequência, Alinne Balduino Pires Fernandes em $O$ teatro de Marina Carr: manutenção e subversão do cânone irlandês apresenta a dramaturga irlandesa contemporânea Marina Carr (1964-), considerada atualmente a mulher de maior reconhecimento no teatro irlandês, mas que é praticamente desconhecida no brasil. O texto analisa a peça By the Bog of Cats... (1998) traduzido pela autora como No Pântano dos Gatos. Sua análise posiciona a dramaturga no cânone irlandês, com obras que subvertem temas recorrentes, figuras de estilo e de linguagem ao se utilizar do grotesco e do carnavalesco.

A seguir, Andrea do Roccio Souto autora de Escrever é ser: heteronímia e escritura no Livro do desassossego analisa o exercício de escritura-processo pessoana marcado pela heteronímia e destaca que ler Pessoa e seus outros na voz de Bernardo Soares é entrar no jogo e mergulhar no mito da multiplicidade.

Por sua vez, apoiada nos conceitos de curadoria e livro de artista, Edma de Góis, no artigo Curadora e livro de artista: caminhos para uma leitura de Valência Xavier considera as aproximações e distanciamentos entre imagem e texto na obra Minha mãe morrendo e o menino mentido (2001). Uma obra com narrativa multimodal em que sistemas semióticos diferentes, como a fotografia, os anúncios publicitários, os mapas etc. são chamados a convergir exigindo, assim, novos protocolos de leitura e de crítica.

Já em Dicionários bizarros: fragmentos poéticos de experiências, Gizelle Kamisnki Corso apresenta a atividade desenvolvida por estudantes no Instituto Federal de Educação, Ciência e Tecnologia de Santa Catarina (IFSC). Trata-se de uma atividade inspirada no livro 
Mania de Explicação de Adriana Falcão e Mariana Massarani, que consiste na elaboração de dicionários - Dicionários Bizarros - cujos verbetes e seus significados sentidos soam como poemas e são fragmentos poéticos de suas experiências.

Em O Inca Garcilaso de la Vega e seu trânsito entre a colônia e a metrópole: revisionismo histórico e literário, a pesquisadora Ximena Antonia Diaz Merino, resgatando a narrativa pessoal do Inca Garcilaso de la Vega, considerada como uma das primeiras fontes escritas por um mestiço que enfrentou a história da conquista, apresenta uma nova versão aos relatos dos cronistas europeus acerca dessa história.

Para fechar a seção, temos o texto Rastros da história colonial na literatura de Paulina Chiziane escrito por Tiago Ribeiro Santos que discute como Paulina Chiziane tece o passado colonial de Moçambique no romance $O$ alegre canto da perdiz. Sua narrativa ficcional apresenta modos de opressão e de resistência para além daqueles veiculados pela narrativa oficial da Frente de Libertação.

A segunda seção da revista abre com o texto de Isabela Melim Borges, Alckmar Luiz dos Santos e Samanta Rosa Maia intitulado Valor e valoração literária em cinco prefácios de livros de poemas do início do século $X X$. O artigo examina o problema da valoração da obra literária fundamentado teoricamente nas reflexões sobre o valor de Jonathan Culler e Wellek $\&$ Warren e paratextos de Gérard Genette.

A seguir, Mariana Chaves Petersen compõe a seção com Sylvia and the absence of life before Ted. Trata-se de um texto apoiado nos argumentos de Linda Hutcheon, Mary E. Hawkesworth e Tracy Brain. A partir desses autores, a escritora argumenta que a cinebiografia Sylvia (Christine Jeffs, 2003) deixa de apresentar algumas passagens da vida de Sylvia Plath, especialmente antes de conhecer seu marido Ted Hughes, e acaba por retratá-la mais como esposa do que como escritora.

Analisando a relação entre corpo e tecnologia e qual a implicância dessas discussões para os estudos de transumanismo e pós-humanismo a partir dos corpos alterados das personagens e as consequências dessas alterações, Luana de Carvalho Krüge e Eduardo Marks de Marques apresentam o texto Transumanos e pós-humanos em deuses de pedra: a valorização do corpo padronizado na distopia de Jeanette Winterson. Os autores consideram que a partir da criação de um corpo ideal promove-se uma ideia errônea de saúde perfeita através da interferência tecnológica,

A edição é finalizada com o texto produzido por Josiele Kaminski Corso Ozelame e Nataly Yolanda Capelari dos Santos, sob o título: Memórias da morte e a (trans)formação de 
sua identidade no romance de Saramago, no qual as autora trabalham com a tríade memóriaidentidade-morte para demonstrar como as memórias construídas cultural e socialmente da morte e de "passados", contribuem para a construção e personificação da personagem principal do romance de José Saramago (2005), As intermitências da morte - a própria morte.

A finalizar esta apresentação, cabe-nos agradecer pelo empenho e pela participação de todas as autoras e de todos os autores que compõem este número e à Equipe do Portal de Periódicos da Biblioteca Universitária da UFSC pelo suporte e apoio imprescindíveis para esta publicação.

Desejamos a todas e a todos boas leituras!

Comissão Editorial.

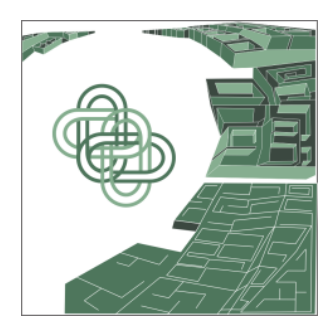

